\title{
ANALISIS KEMAMPUAN TEKNIK DASAR BERMAIN SEPAKBOLA PADA PEMAIN USIA 16 TAHUN
}

\author{
Martha Wira Utama \\ PJKR FKIP UNIB, e-mail: marthawirutama@gmail.com \\ Bayu Insanistyo \\ Universias Bengkulu \\ Syafrial \\ Universitas Bengkulu
}

\begin{abstract}
Abstrak
Penelitian ini bertujuan untuk mengetahui kemampuan teknik dasar bermain sepakbola pada pemain usia 16 Tahun. Jenis penelitian ini adalah penelitian yang bersifat deskriptif analisis yang menggunakan pendekatan kuantitatif. Maksudnya adalah sember data yang diperoleh dari 53 pemain yang termasuk dalam tim SSB pada usia 16 tahun di Kabupaten Rejang Lebong. Berdasarkan hasil data diperoleh dari 53 pemain usia 16 tahun di SSB kabupaten Rejang Lebong diperoleh hasil dengan persentase $57,77 \%$ pemain yang didominasi dalam kategori sedang. Berdasarkan hasil penelitian tersebut dapat disimpulkan bahwa kemampuan teknik dasar bermain sepakbola pada pemain usia 16 tahun belum bagus atau baik, Faktor yang mempengaruhi pemain belum memiliki kemampuan teknik dasar sepakbola yang baik adalah program latihan yang tidak teratur yang dilakukan 1 (satu) kali dalam seminggu, dan fasilitas pendukung latihan yang kurang bagus.
\end{abstract}

Kata kunci : Analisis, Kemampuan Teknik Dasar

\begin{abstract}
This study aims to determine the basic techniques of playing football skills at the age of 16 years. The type of this research is descriptive research that uses a quantitative approach. The intention is sember data obtained from 53 players who are included in the SSB team at the age of 16 years. Based on the data obtained from 53 players aged 16 years in 4 SSB Rejang Lebong district obtained results with the percentage of $57,77 \%$ of players dominated in the category of being. Based on the results of this study can be concluded that the basic techniques of playing football at the age of 16 players know is not good or good, Factors that affect the players do not have the basic skills of good football technique is an irregular exercise program conducted 1 (one) time in a week, and training facilities that support less good.
\end{abstract}

Keywords: Analysis, Ability of Basic Techniques 


\section{PENDAHULUAN}

Dalam upaya menggapai prestasi yang baik maka pembinaan harus dimulai dari pembinaan usia dini dan atlet muda berbakat sangat menentukan menuju tercapainya mutu prestasi optimal dalam cabang olahraga sepakbola. Bibit atlet yang unggul perlu pengolahan dan proses kepelatihan secara ilmiah, barulah muncul prestasi atlet semaksimal mungkin pada umur-umur tertentu. Dalam usaha pembinaan prestasi olahraga sepakbola, diperlukan unsur pendukung yang sangat vital. Salah satu unsur tersebut adalah pelatih yang berpendidikan. Pelatih yang berpendidikan adalah pelatih yang memahami dengan baik masalah-masalah yang menyangkut kepelatihan, sebuah klub akan mempunyai peluang yang jauh lebih besar untuk berhasil dan berprestasi daripada klub yang tidak menggunakan pelatih yang tidak mempunyai dasar dalam ilmu kepelatihan. Selain latihan kemampuan dasar, yang perlu diperhatikan juga adalah latihan fisik. Latihan dapat dilakukan sendiri atau terkoordinasi dalam sebuah klub atau pusat pelatihan. Kondisi fisik adalah satu kesatuan untuh dari komponen-komponen yang tidak dapat dipisah-pisahkan, baik peningkatannya maupun pemeliharaannya, artinya dalam usaha peningkatan kondisi fisik harus mengembangkan semua komponen tersebut. Di kabupaten Rejang Lebong provinsi Bengkulu sangat memperhatikan pemain-pemain sepakbola yang handal terutama dalam pembinaan usia 16 tahun, tepatnya pada pembinaan kemampuan dasar sepakbola. Bukan hal baru Rejang lebong sangat memperhatikan hal itu karna sangat berperan penting pada kemajuan olahragannya terutama sepakbola.Dengan kondisi goegrafis kabupaten Rejang Lebong yang berada di pegunugan dan letak antar kecamatan yang berjauhan membuat pemerintah sulit untuk mencari bibit-bibit handal sepak bola usia dini tepatnya yang telah baik dalam kemampuan dasar sepak bola di usia 16 tahun, hal itu juga sangat berpengaruh pemerintah untuk mencari SSB yang berprestasi terutama diusia dini guna menyaring pemain-pemain handal di SSB yang berprestasi untuk membentuk satu Tim yaitu Persatuan Sepak Bola Rejang Lebong (PERSIREL) usia 16 tahun. Dengan demikian hal ini sangat menjadi ketertarikan peneliti untuk melakukan penelitian dengan judul :"ANALISIS KEMAMPUAN TEKNIK DASAR BERMAIN SEPAKBOLA PADA PEMAIN USIA 16 TAHUN".

\section{METODE}

Jenis Penelitian

Berdasarkan permasalahan yang akan dibahas dalam penelitian ini, maka jenis penelitian ini adalah jenis penelitian deskriptif yang menggunakan pendekatan kuantitatif. Penelitian deskriptif yang mengambarkan kemapuan teknik dasar bermain sepakbola pada pemain usia 16 tahun di Kabupaten Rejang Lebong, melalui observasi atau pengamatan langsung, maksudnya penelitian ini adalah melihat langsung hasilnya dan tidak melihat dari proses awal, selanjutnya mencari penyebab masalah tersebut.

Sugiyono (2006: 6) menyatakan bahwa metode suvey digunakan untuk mendapatkan data dari tempat tertentu yang alamiah (bukan buatan), tetapi peneliti melakukan perlakuan dalam pengumpulan data, misalnya dengan mengedarkan kuesioner, tes, wawancara dan sebegainya.Berdasarkan penjelesan peneliti akan mengambil data di lapangan. 


\section{POPULASI DAN SAMPEL}

Populasi

Populasi adalah wilayah generalisasi yang terdiri atas: Obyek/subyek yang mempunyai kualitas karakteristik tertentu yang ditetapkan oleh peneliti untuk mempelajari dan kemudian ditarik kesimpulannya, (Sugiyono, 2006: 89). Populasi dalam penelitian ini adalah Sekolah Sepakbola(SSB) se-Kabupaten Rejang Lebong.

Table

1.

Nama

SekolahSepakbola(SSB)

di Kabupaten Rejang Lebong

\begin{tabular}{|l|l|l|}
\hline No & Nama SSB & Ket \\
\hline 1 & SSB Adiyasa & Curup Tengah \\
\hline 2 & SSB Matador & Curup Selatan \\
\hline 3 & SSB Rejang Lebong & Curup Selatan \\
\hline 4 & SSB Buana & Selupu Rejang \\
\hline 5 & SSB Graha Nusantara & Curup Tengah \\
\hline 6 & SSB Btn & Curup Tengah \\
\hline 7 & SSB Pkdp & Curup Timur \\
\hline 8 & SSB Backang & Curup Selatan \\
\hline 9 & SSB Tunas Muda & Curup Utara \\
\hline
\end{tabular}

\section{Sampel}

Sampel adalah bagian atau wakil dari populasi yang diteliti (Suharsimi Arikunto, 2010: 95). Dalam penelitian ini pengambilan sampel menggunakan teknik cluster sampling yang termasuk dalam probability sampling. Menurut Sugiyono, (2006: 91) sampling probability adalah teknik pengambilan sampel yang memberikan peluang yang sama bagi setiap unsur (anggota) populasi yang dipilih menjadi anggota sampel yaitu 53 pemain yang masuk dalam tim usia 16 tahun di SSB kabupaten Rejang Lebong, Yang dimaksud dengan tim SSB pada usia 16 tahun tersebut adalah pemain yang diseleksi berdasar kan umur yang belum melewati usia 16 tahun atau pemain tidak boleh lebih dari usia 16 tahun di SSB kabupaten Rejang Lebong, Berikut sampel 4 SSB di kabupaten Rejang Lebong .

Table 2. Nama SekolahSepakbola (SSB) Yang Aktif di Kabupaten Rejang Lebong

\begin{tabular}{|l|l|l|}
\hline No & Nama SSB & Ket \\
\hline 1 & SSB Adiyasa & Curup Tengah \\
\hline 2 & SSB Matador & Curup Selatan \\
\hline 3 & SSB Rejang Lebong & Curup Selatan \\
\hline 4 & SSB Graha Nusantara & Curup Tengah \\
\hline
\end{tabular}

Tempat dan Waktu Penelitian

a. Tempat Penelitian

Tempat penelitian ini dilakukan di lapangan latihan sepakbola SSB kabupaten Rejang Lebong.

b. Waktu Penelitian

Penelitian dilakukan selama 1 bulan terhitung sejak dikeluarkann surat izin meneliti hingga batas waktu yang ditentukan.

Instrumen Penelitian

Untuk memperoleh data yang relevan dan akurat maka diperlukan alat pengukur data yang dapat dipertanggung jawabkan, yaitu alat ukur, karena instrumen penelitian yang baik harus memenuhi persyaratan yang valid atau terukur (Suharsimi Arikunto, 1998: 135):

Teknik Pengumpulan Data

Teknik untuk memperoleh data di lapangan melalui tes terhadap sample melakukan teknik kemampuan dasar sepakbola adalah tes langsung, dengan kata lain data diperoleh melalui tes. 
Instrumen Pengumpulan Data

Tes untuk mengukur kemampuan dasar shooting

Tes yang dapat digunakan adalah menendang bola dari tempat dengan kaki tertentu ke sasaran yang telah ditentukan.

Tujuan : Tes ini untuk mengukur ketepatan shooting dalam sepakbola.

Prosedur Tes : 1) Alat dan fasilitas, 2) Alat-alat tulis, 3) Bola sepak(berjarak $10 \mathrm{~m}$ dari gawang), dan 4) Tembok sasaran yang berukuran 5 meter $x$ lebar 2 meter. 5) Sasaran : Tembok sasaran.

a. Pelaksanaan Tes

1) Bola disusun pada garis serangan dengan komposisi 2 bola berada dikanan, 2 bola di kiri dan 2 bola ditengah

2) Peserta tes berdiri pada jarak 1 meter pada bola yang akan ditendang ke arah gawang

3) Peserta tes menendang bola 2 kali dengan kaki kanan ke arah sasaran gawang

4) Peserta tes menendang bola 2 kali dengan kaki kiri ke arah sasaran gawang

5) Peserta tes menendang bola 2 kali dengan kaki yang paling sesuai ke arag gawang sasaran.

Pencatatan hasil diambil dari jumlah 6 kali tendangan dikalikan dengan jumlah sasaran.

Tes untuk mengukur kemampuan menggiring bola/dribbling.

Tes dribbling adalah tes menggiring bola secepat mungkin melewati semua rintangan yang telah di tentukan seperti Tes dribbling zig-zag
Tujuan : Tes ini bertujuan untuk mengukur kemampuan menggiring bola/dribbling.

a. Alat dan fasilitas : 1. Cone (ditaruh sebanyak 8 coon pada jarak $1 \mathrm{~m}$ antara (cone), 2.Bola sepak, 3. Stopwatch, 4. Lapangan sepakbola

b. Sasaran

c. Cone yang akan dilewati

Test short Passed

Test short Passed adalah tes menendang bola dengan beberapa tempat dan kesasaran tertentu dalam waktu tercepat.

Tujuan : Tes ini bertujuan untuk mengukur kemampuan peserta tes dalam melakukan passing secara cepat dan tepat. Pelaksanaan tes peserta berada dibelakang garis start, pada aba-aba "ya" peserta lari kearah bola 1 dan menendang kesasaran 1, lari kearah bola 2 dan menendang kesasaran 2, lari ke arah bola 3 dan menendang kesasaran 3, lari ke bola 4 dan menendang ke sasaran 4 dan akhirnya lari menuju garis finish.

Tes Heading (Menyundul Bola)

Tes Heading merupakan tesmenyundul bola sejauh mungkin pada tempat tertentu, dan lambungan awal dilakukan sendiri.

Tujuannya: Unuk mengukur otot leher pada saat melakukan sundulan bola.

Pelaksanaannya adalah:

a. Pelaksana tes berada di hadapan peserta tes yang tidak jauh dari sasaran jatuhnya bola yang akan disundul oleh peserta tes

b. Peserta tes berada pada garis start dengan memegang sebuah bola 
c. Peserta tes melambungkan bola ke atas, melentingkan tubuh pada saat bola menurun maka disambut dengan kepala peserta tes untuk melakukan sundulan sejauh mungkin

d. Pelaksana tes menuju jatuhnya bola untuk memberikan tanda dan melakukan pengukuran langsung

e. Sundulan ini dilakukan sebanyak 3 kali.

Pencatatan hasil diambil dari jarak yang terjauh dari 3 kali melakukan.

\section{HASIL DAN PEMBAHASAN} Hasil

Berdasarkan hasil data variabel passing, dribbling,heading dan shooting, ternyata dari 53 Pemain yang termasuk dalam tim yang dikategorikan dalam usia 16 tahun dikabupaten Rejang Lebong, diperoleh hasil yang didominasi pada kategori sedang pada jumlah keseluruhan hasil tes kemampuan teknik dasar dengan prolehan 109 yang dikategorikan tes kemampuan teknik dasarnya sedang dari 53 pemain pada tes passing, dribbling, heading dan shooting, dengan persentase sebesar $57,77 \%$. Dari hasil data tes kemampuan teknik dasar SSB Matador lebih baik dibandingkan SSB adiyasa, SSB Rejang Lebong dan SSB Graha Nusantara. Berdasarkan hasil analisis tersebut berarti kemampuan dasar sepakbola pada pemain usia 16 tahun di SSB kabupaten Rejang Lebong dalam permainan sepakbola belum memuaskan. Hal ini dapat diinterprestasikan bahwa ada beberapa faktor yang dapat mempengaruhi baik dan buruknya kemampuan dasar sepakbola pada usia 16 tahun di SSB kabupaten Rejang Lebong yaitu :

1. Kurangnya waktu pemain dalam mendalami setiap kemampuan dasar dibidang sepakbola. Karena program latihan yang kurang teratur dan baik yang hanya dilakukan 1 kali dalam seminggu. Tentu saja waktu tersebut sangat kurang.

2. Setiap cabang olahraga memiliki latihan tersendiri dalam meningkatkan kemampuan dasar cabang olahraga tersebut, seperti push-up, jogging, dan lain-lain. Semua itu juga dibutuhkan dalam proses meningkatkan kemampuan dasar pada permainan sepakbola, sehingga sedikit membantu pemain dalam hal kecepatan dan kekuatan. Hanya saja dalam hal kemampuan dasar pemain sepakbola pada usia 16 tahun di Kabupaten Rejang Lebong tergolong rendah, karena tidak semua pemain bisa menguasai kemampuan dasar dalam permainan sepakbola dengan cepat.

Hal ini menunjukkan bahwa sebagian besar pemain sepakbola pada usia 16 tahun di kabupaten Rejang Lebong dan yang terpilih sebagai sampel dalam penelitian " Analisis kemampuan teknik dasar bermain sepakbola pada pemain usia 16 tahun di Kabupaten Rejang Lebong tergolong rendah perlu dan perlu ditingkatkan lagi pada pemain yang memiliki kemampuan teknik dasar sepakbola yang dikategorikan kurang dan kurang sekali, maupun yang dikategorikan sedang dan baik dalam kemampuan dasar sepakbola .

Dalam skor tersebut dapat disimpulkan bahwa kemampuan teknik dasar bermain sepakbola pada pemain usia 16 tahun di SSB kabupaten Rejang Lebong masih tergolong sedang dengan persentase sebesar $57,77 \%$ karena program latihan 
yang kurang teratur dan baik yang hanya dilakukan 1 kali dalam seminggu.

\section{Pembahasan}

Pembahasan ini akan membahas penguraian hasil penelitian tentang analisis kemampuan teknik dasar bermain sepakbola pada pemain usia 16 tahun di kabupaten Rejang Lebong. Permainan sepakbola merupakan salah satu cabang olahraga yang sangat populer didunia, Dengan jumlah yang dimainkan oleh 11 orang dengan tujuan mencetak gol kegawang lawan, setiap pemain memiliki tugas dan peran yang sama yaitu harus mampu menyerang dan bertahan dengan baik. Maka penguasaan teknik dasar yang baik dari setiap pemain mutlak sangat dibutuhkan, sehingga penguasaan bola dapat dikendalikan dan lebih dapat memaksimalkan bola dalam situasi-situasi apapun. Berdasarkan pada deskripsi data dan olahan data mengenai "Analisis Kemampuan Teknik Dasar Bermain Sepakbola Pada Pemain Usia 16 di Kabupaten Rejang Lebong", maka dapat dikemukakan jawaban pertanyaan sesuai dengan rumusan masalah yang telah diajukan sebelumnya yaitu "Bagaimanakah kemampuanTeknik dasar bermain sepakbola pada pemain usia 16 tahun di SSB kabupaten Rejang Lebong ?" yang berkenaan dengan kemampuan dasar passing, dribbling, heading dan shooting. Untuk lebih jelasnya jawaban dari pertanyaan dapat diuraikan sebagai berikut. Berdasarkan hasil data variabel passing, dribbling,heading dan shooting, ternyata dari 53 Pemain yang termasuk dalam tim yang dikategorikan dalam usia 16 tahun dikabupaten Rejang Lebong, diperoleh hasil yang didominasi pada kategori sedang pada jumlah keseluruhan hasil tes kemampuan teknik dasar dengan prolehan 109 yang dikategorikan tes kemampuan teknik dasarnya sedang dari 53 pemain pada tes passing, dribbling,heading dan shooting, dengan persentase sebesar 57,77\%. Dari hasil data tes kemampuan teknik dasar SSB Matador lebih baik dibandingkan SSB adiyasa, SSB Rejang Lebong dan SSB Graha Nusantara. Berdasarkan hasil analisis tersebut berarti kemampuan dasar sepakbola pada pemain usia 16 tahun di SSB kabupaten Rejang Lebong dalam permainan sepakbola belum memuaskan

\section{PENUTUP}

\section{Kesimpulan}

Berdasarkan pada hasil penelitian yang telah peroleh dari variabel Shooting, Dribbling, Passing dan Heading maka dapat diambil kesimpulan bahwa kemampuan teknik dasar bermain sepakbola pada pemain usia 16 tahun di Kabupaten Rejang Lebong masih tergolong sedang dengan persentase pemain sebanyak $57,77 \%$ yang termasuk dalam kategori rata-rata sedang, Dari kesluruhan data yang diproleh SSB Matador mempunyai teknik dasar bermain sepakbola lebih baik dari SSB Adiyasa, SSB Rejang Lebong, dan SSB Graha Nusantara Dengan Banyaknya pemain yang masuk dalam kategori teknik kemampuan dasarnya sedang.

Adapun faktor yang menyebabkan kurangnya teknik kemampuan dasar bermain sepak bola pada pemain usia 16 tahun dikarenakan program latihan yang kurang teratur dan baik yang hanya dilakukan 1 kali dalam seminggu yang mempengaruhi tidak stabilnya kemampuan teknik dasar sepakbola pada pemain usia 16 tahun tersebut, Dengan banyaknya pemain yang masuk dalam kategori sedang dan tidak adanya pemain yang masuk dalam kategori baik sekali maka akan berdampak pada prestasi yang diproleh oleh pemain maupun tim dan pelatih. 


\section{Saran}

Ada beberapa saran yang perlu disampaikan sehubungan dengan hasil penilitian ini antara lain:

1. Sesuai dengan hasil penilitian diketahui bahwa kemampuan teknik dasar sepakbola mempunyai tingkat keberhasilan yang termasuk rendah, Kemampuan teknik dasar merupakan hal yang cukup sederhana dilakukan tetapi apabila dimaksimalkan dalam latihan maka hasil dan manfaat yang diproleh akan sangat baik.

2. Dengan banyak pemain yang masuk kategori sedang, hal ini dapat dijadikan bahan kajian bagi para pelatih untuk meningkatkan dan lebih memaksimalkan kemampuan teknik dasar bermain sepakbola pada SSB di kabupaten Rejang Lebong.

3. Penelitian ini juga bertujuan sebagai refensi pelatih dimana pelatih bisa mengetahui dimana letak kekurangan timnya sehingga bisa memperbaiki tim sepakbola tersebut agara menjuarai setiap kompetisi.

4. Hasil penelitian ini juga digunakan sebagai bahan evaluasi bagi pelatih untuuk mengetahui kemampuan pemainnya.

\section{DAFTAR PUSTAKA}

Abdul Rohim. (2008). Bermain Sepakbola. Semarang: CV. Aneka Ilmu

Andi Cipta. (2012). Mahir Sepakbola. Bandung: Nuansa Cendeka.
Danny Mielke. (2007). Dasar-Dasar Sepak Bola. Bandung: PT Intan Sejati.

Leo, Arwin, dan Syafrial. 2017. "Profil Kondisi Fisik Pemain Sepak Bola SMA Negeri 1 Kaur" Jurnal Kinestetik, Vol. 1 (1).

Nana Sudjana. (2012).Penilaian Hasil Proses Belajar Mengajar. Bandung: PT Remaja Rosdakarya Offset.

Sugiyo. (2006). Metode Peneletian Kuantitatif, Kualitatif dan R \& D. Bandung: ALFAVETA, cv.

Sutrisno. (2009). Pemain Sepakbola Berprestasi. PT Musi Jakarta Utama.

Tangkudung, James. (2012). Kepelatihan Olahraga Pembinaan Prestasi Olahraga. Jakarta: Cerdas jaya ,(2016).Macam-macam Metodologi Penelitian. Jakarta: Lensa Media Pustaka Indonesia ,(2018). Sport Psychometrics Dasar-dasar dan instrument Psikometri. Depok :Rajagrafindo persada 